Мокриков Г.В., Минникова Т.В., Казеев К.Ш., Колесников С.И. 03.02.00 - общая биология Влияние запасов продуктивной влаги и количества атмосферных осадков на урожайность..

поглощению углерода на территории России // Почвоведение. 2015. № 9. С. 1049-1060.

29. Акименко Ю.В., Мокриков Г.В., Казеев К.Ш., Колесников С.И. Влияние технологии прямого посева на микробиологические свойства черноземов. Ростов-на-Дону: Изд-во ЮФУ, 2016. 96 с.

30. Мокриков Г.В., Казеев К.Ш., Акименко Ю.В., Колесников С.И. Влияние технологии прямого посева на эколого-биологические свойства черноземов // Известия высших учебных заведений. Северо-Кавказский регион. 2017. № 2. С. 68-74.

31. Kazeev K.S., Mokrikov G.V., Akimenko Y.V., Kolesnikov S.I. Effect of no-till on the physical properties of south Russia soil // International Multidisciplinary
Scientific GeoConference Surveying Geology and Mining Ecology Management, SGEM 2017. 2017. Vol. 17 (32). P. 185-192. DOI: 10.5593/sgem2017/32/S13.025.

32. Mokrikov G.V., Kazeev K.Sh., Akimenko Yu.V., Myasnikova M.A., Kolesnikov S.I. Influence of the NoTill technology on the enzymatic activity of different chernozems of Southern Russia // 18th International Multidisciplinary Scientific GeoConference SGEM 2018: Conference Proceedings. 2018. Vol. 18. P. 257-264.

Статья публикуется при поддержке Министерства образования и науки Российской Федерации (5.5735.2017/8.9) и Президента Российской Федерации (НШ-3464.2018.11).

\title{
INFLUENCE OF DIRECT SEEDING ON THE YIELD OF AGRICULTURAL CULTURES IN THE ROSTOV REGION
}

(C) 2019

Mokrikov Gregory Vasilyevich, candidate of agricultural sciences, researcher of Ecology and Nature Management Department of Academy of Biology and Biotechnology named after D.I. Ivanovsky Minnikova Tatiana Vladimirovna, junior researcher of Ecology

and Nature Management Department of Academy of Biology and Biotechnology named after D.I. Ivanovsky Kazeev Kamil Shagidullovich, doctor of geographical sciences, professor of Ecology and Nature Management Department of Academy of Biology and Biotechnology named after D.I. Ivanovsky

Kolesnikov Sergey Ilyich, doctor of agricultural sciences, professor, head of Ecology and Nature Management Department of Academy of Biology and Biotechnology named after D.I. Ivanovsky Southern Federal University (Rostov-on-Don, Russian Federation)

Abstract. Tillage technologies that promote resource conservation and increase crop yields, especially in conditions of dry climate, are increasingly being introduced into the Russian agriculture. However, taking into account a diversity of soil and climatic conditions in Russia, it is necessary to study the agro-ecological state of agro landscapes. In Russia, in recent years, an increase in the yield of winter wheat and sunflower has been observed. From 2014 to 2018 in production conditions in the Rostov Region, the effect of direct sowing technology (No-Till) on the yield of winter wheat and sunflower was studied. The yield of sunflower and winter wheat largely depended on the amount of precipitation during the critical growing season of each agricultural crop. In 2014-2017 the yield of winter wheat in agrocenoses using direct sowing technology increased by $26-114 \%$, sunflower by $27-92 \%$ compared with the traditional technology. The authors show that direct seeding compared to traditional technology of dump plowing (traditional tillage) contributes to saving motor fuel, increasing crop yields and lowering the cost of the main crops of the Rostov Region: winter wheat and sunflower.

Keywords: ecosystem; green technology; nature-like technologies; agrocenoses; humidity; growing season; ordinary chernozem; direct seeding; zero technology; traditional tillage; resource saving; nature-like technologies; agrocenoses; soil condition; winter wheat; sunflower; yield; fertility.

УДК 581.9

DOI 10.24411/2309-4370-2019-11112

Статья поступила в редакцию 04.09.2018

\section{ИЗУЧЕННОСТЬ ГАЛОФИТНОЙ РАСТИТЕЛЬНОСТИ ПЕНЗЕНСКОЙ ОБЛАСТИ И ЕЕ ОХРАНА} (C) 2019

\author{
Новикова Любовь Александровна, доктор биологических наук, доцент, \\ профессор кафедры общей биологии и биохимии \\ Пензенский государственный университет (2. Пенза, Российская Федеращия) \\ Васюков Владимир Михайлович, кандидат биологических наук, \\ научный сотрудник лаборатории проблем фиторазнообразия \\ Институт экологии Волжского бассейна РАН (2. Тольятти, Самарская область, Российская Федерация) \\ Горбушина Татьяна Викторовна, кандидат сельскохозяйственных наук, старший научный сотрудник \\ Государственный природный заповедник «Приволжская лесостепь» (2. Пенза, Российская Федераиия)
}

Аннотащия. Всего в Пензенской области в настоящее время выявлено и описано 15 участков с засоленными почвами, из которых только 2 имеют статус памятника природы: «Солонцовая степь» в Лунинском районе и «Даниловская солонцовая поляна» в Малосердобинском районе. Предлагаем включить в существующую систему ООПТ Пензенской области в качестве памятников природы еще 13 урочищ: в Колышлейском районе - «Жмакинский солонец», «Кайсаровский солонец»; в Лопатинском - «Литвиновский солонец»; в Малосердобинском - «Чунакская солонцовая поляна», «Корзовая лощина»; в Неверкинском - «Келлеровский солонец», «Мансуровский солонец», «Карноварский солонец»; в Пензенском - «Ольшанский со- 
лонец», «Андреевский солонец», «Васильевский солонец»; в Сердобском - «Сердобский солонец», «Красный солонец». По каждому участку приводятся данные по истории открытия, расположению и привязкам к населенным пунктам, указывается принадлежность к бассейнам крупных рек, приблизительная площадь, сведения о характере хозяйственного использования в прошлом и степени антропогенных нарушений, дается характеристика рельефа и почв. Главное внимание уделено описанию характера распространения галофитной растительности в зависимости от степени засоления и увлажнения почв. Также приводятся данные по растительности степей, лугов и болот, встречающихся в описанных урочищах. Перечисляются доминирующие и уникальные виды сосудистых растений.

Ключевые слова: галофитная растительность; галофиты; Пензенская область; особо охраняемые природные территории; памятники природы; Красная книга; редкие виды; галофитные степи; солонцеватые низинные болота; галофитные луга; солонцы; засоленные участки; охрана уникальных видов и сообществ.

В Пензенской области галофитная флора и растительность занимает северную границу распространения засоленных почв и поэтому нуждается в охране и изучении. Сведения о галофитной растительности фрагментарны и содержатся в немногих работах известных исследователей $[1 ; 2$, с. $120-131 ; 3$, с. 181 182; 4, с. 93-104].

В Пензенской области только два участка с засоленными почвами обладают охранным статусом. К ним относятся следующие памятники природы: в Лунинском районе - «Солонцовая степь» (Постановление Законодательного собрания Пензенской области № 676-30/23С от 26 декабря 2000 г.) и в Малосердобинском районе - «Даниловская солонцовая поляна» (Постановление Законодательного собрания Пензенской области и № 587-25/23С от 14 июля 2000 г.) [5, с. $105 ; 6 ; 7$, с. 229].

В настоящее время были обнаружены новые участки с галофитной растительностью. Для этого были привлечены существующие гербарные фонды (PKM, MW, LE), также последние флористические сводки по Пензенской области [8; 9] и другие литературные источники: Красные книги Пензенской области [10] и Российской Федерации [11] и др. Латинские названия видов приводятся в основном по базе данных Euro + Med Plantbase [12].

Количество засоленных участков постоянно возрастает. Сначала было известно всего десять солонцов $[13 ; 14]$, позже к ним добавились еще два («Мансуровский» и «Келлеровский» в Неверкинском районе) $[15$, с. $34 ; 16$, с. $177-178 ; 17$, с. $190 ; 18-24]$, а в последнее время - еще три (в Лопатинском районе - «Литвиновский солонец», в Малосердобинском районе - «Корзовая лощина», в Неверкинском районе - «Карноварский солонец»).

В последние годы галофитная растительность Среднего Поволжья интенсивно изучается сторонниками школы Браун-Бланке [25; 26], но их исследования не затронули территории Пензенской области.

В настоящее время в Пензенской области обнаружено уже пятнадцать солонцов в разных административных районах: два («Жмакинский солонец», «Кайсаровский солонец») - в Колышлейском; один («Литвиновский солонец») - в Лопатинском; один («Солонцовая степь») - в Лунинском; три («Даниловская солонцовая поляна», «Корзовая лощина», «Чунакская солонцовая поляна») - в Малосердобинском; три («Карноварский солонец», «Келлеровский солонец» и «Мансуровский солонец») - в Неверкинском, три («Андреевский солонец», «Васильевский солонец», «Ольшанский солонец») - в Пензенском; два («Красный солонец», «Сердобский солонец») - в Сердобском районах.

В Колышлейском районе в настоящее время нами описаны только два засоленных участка: «Жма- кинский солонец» и «Кайсаровский солонец». Они оба располагаются в пойме левого притока р. Хопер - p. Колышлей (Донской бассейн).

«Жмакинский солонец», впервые обнаруженный Б.А. Келлером еще в 1901 г. [2, с. 131; 14; 27 , c. 513-514], располагается у с. Жмакино, занимает площадь 100 га и отличается богатой флорой. Растительность носит выраженный комплексный характер в связи с разной степенью увлажненности и засоленности разных геоморфологических элементов.

На возвышенных элементах рельефа в условиях наибольшего засоления почв образуются полукустарничковые (Artemisia santonica L.) и многолетнеразнотравные (Limonium donetzicum Klokov, Galatella linosyris (L.) Rchb. f., Artemisia pontica L.) галофитные степи. В них встречаются такие редкие виды, как Artemisia pontica L., Plantago maxima Jacq., P. cornuti Gouan.

На пониженных элементах рельефа образуются разнообразные варианты галофитных лугов: дерновиннозлаковые (Puccinellia distans (Jacq.) Parl.), корневищноситниковидные (Triglochin maritima L.), многолетнеразнотравные (Taraxacum bessarabicum (Hornem.) Hand.-Mazz., Plantago maxima Jacq., Plantago cornuti Gouan с участием Glaux maritima L.) и однолетнеразнотравные (Tripolium pannonicum (Jacq.) Dobrocz.) с участием Triglochin maritina L., Juncus compressus Jacq., Plantago salsa Pall., Scorzonera parviflora Jacq.

В условиях меньшего засоления почв развиваются ассоциации с преобладанием Carex diluta M. Bieb., Galatella linosyris (L.) Rchb. f. и участием Jacobaea vulgaris Gaertn., Cirsium canum (L.) All., Serratula tinctoria L. В этой ассоциации встречаются: Jacobaea kirghisica (DC.) E. Wiebe, Gladiolus tenuis M. Bieb., Iris halophila Pall., Dactylorhiza incarnata (L.) Soo, Cenolophium denudatum (Hornem.) Tutin, Sium sisaroideum DC., Ptarmica salicifolia (Besser) Serg. и др.

Переувлажненные места заняты болотной растительностью из Phragmites australis (Cav.) Trin. ex Steud. и разных видов Carex; отмечаются также: Glaux maritima L., Filipendula ulmaria (L.) Maxim., Thalictrum flavum L. Здесь встречаются небольшие заросли кустарников из Salix cinerea L. и S. vinimalis L., a также небольшое осоковое болото с господством Carex omskiana Meinsh. и участием Symphytum officinale L., Veratrum lobelianum Bernh., Caltha palustris L., Trollius europaeus L., Calamagrostis canescens (Web.) Roth. На берегу водоема отмечаются редкие виды: Carex hartmannii Cajander и Ranunculus lingua L.

На небольшом заброшенном кладбище представлены фрагменты дерновиннозлаковых луговых степей с доминированием Stipa pennata L. и участием Thymus marschallianus Willd., Galium ruthenicum Willd., 
Coronilla varia L., Artemisia pontica L., Melampyrum argyrocomum (Fisch. ex Ledeb.) Koso-Pol. и др.

Растительность соседних с солонцом разновозрастных залежей находится на начальных этапах восстановления: «бурьянистой» (Cirsium setosum (Willd.) Besser) и «корневищной» (Elytrigia repens (L.) Nevski), а также отмечаются Hieracium virosum Pall., Jacobaea erucifolia (L.) G. Gaertn. et al., J. vulgaris Gaertn., Trifolium alpestre L., Gypsophila paniculata L. и даже отдельные дерновины Stipa pennata L.

«Кайсаровский солонец» (найден А.И. Ивановым в 2006 г.) имеет примерно такую же площадь (100 га) и также окружен многолетними разновозрастными залежами [13, с. 159]. Растительность тоже носит выраженный комплексный характер в связи с выраженным микрорельефом: на наиболее повышенных и засоленных элементах образуются полукустарничковые (Artemisia santonica L.) и многолетнеразнотравные галофитные степи (Galatella linosyris (L.) Rchb. f., Limonium donetzicum Klokov), a на пониженных и менее засоленных - дерновиннозлаковые (Puccinellia distans (Jacq.) Parl.) и многолетнеразнотравные (Taraxacum bessarabicum (Hornem.) Hand.-Mazz.) галофитные луга с участием Silaum silaus (L.) Schinz et Thell. В условиях интенсивного антропогенного воздействия галофитные луга получают широкое распространение и на повышенных участках солонца.

При меньшем засолении залежная растительность находится на «корневищном» этапе восстановления, где образуются корневищнозлаковые настоящие луга (Bromopsis inermis (Leyss.) Holub и Elytrigia repens (L.) Nevski) с довольно большим участием бобовых (Trifoilium medium L.) и разнотравья (Galium ruthenicum Willd., Artemisia pontica L., Salvia stepposa Schost., Phlomoides tuberosa (L.) Moench, Veronica sclerophylla Dubovik). Отмечаются также и редкие галофитные виды: Jacobaea erucifolia (L.) G. Gaertn. et al. и J. kirghisica (DC.) E. Wiebe.

В условиях избыточной влажности формируются солонцеватые низинные болота из Typha latifolia L. и Phragmites australis (Cav.) Trin. ex Steud. с участием гигрофильного разнотравья (Lythrum virgatum L., Lycopus europaeus L.). Рядом встречаются Iris halophila Pall. и Tripolium pannonicum (Jacq.) Dobrocz.

Ближе к руслу реки развиваются ассоциации остепненных лугов, в которых доминирует Calamagrostis epigeios (L.) Roth с участием бобовых - Trifolium arvense L., а из разнотравья - Jacobaea erucifolia (L.) G. Gaertn. et al., J. kirghisica (DC.) E. Wiebe, Cirsium esculentum (Siev.) C.A. Mey., Carex diluta M. Bieb., Ononis arvensis L. Появляются отдельные кусты разных видов Salix и Rosa.

В Лопатинском районе в 2017 г. В.М. Васюковым, Л.А. Новиковой, Т.И. Пчелинцевой в результате целенаправленных поисков был обнаружен еще один засоленный участок - «Литвиновский солонец». Он назван в честь знаменитого ботаника Д.И. Литвинова, который впервые собрал здесь галофитные виды. Участок находится в 3-4 км севернее с. Даниловка (площадь - 300 га) на водоразделе двух левых притоков р. Узы - pр. Чардым и Няньга (Волжский бассейн). Галофитная растительность здесь прежде была распахана и находится на разных этапах восстановления. Участок окружают сообще- ства луговой степи, лесных опушек, прибрежноводная растительность искусственного пруда.

Растительность носит выраженный комплексный характер, связанный с разной степенью засоленности и увлажненности почв. На повышенных местах при большем засолении почв преобладают сообщества полукустарничковых (Artemisia nitrosa Weber et Stechm. с участием Allium praescissum Rchb.), многолетнеразнотравных (Plantago salsa Pall.) и однолетнеразнотравных (Polygonum salsugineum M. Bieb.) галофитных степей; при меньшем засолении - сообщества многолетнеразнотравных галофитных степей с господством Galatella linosyris (L.) Rchb. f. и Artemisia pontica L. На пониженных участках в более влажных условиях получают распространение сообщества многолетнеразнотравных (Silaum silaus (L.) Schinz et Thell., Cirsium esculentum (Siev.) C.A. Mey.), дерновиннозлаковых (Puccinellia tenuissima Litv. ex V.I. Krecz.) и однолетнеразнотравных (Polygonum novoascanicum Klokov) галофитных лугов.

На участке можно встретить самые начальные этапы восстановления галофитной растительности: однолетнеразнотравные галофитные степи (Polygomum salsugineum M. Bieb.) и однолетнеразнотравные галофитные луга (Polygonum novoascanicum Klokov), которые особенно расширяют свою площадь при усилении антропогенного воздействия на растительность.

В Лунинском районе подробно изучен только один засоленный участок - памятник природы «Солонцовая степь» у с. Мерлинка, который был впервые описан И.И. Спрыгиным в его работе, изданной после его смерти [4, с. 101-104].

Объект расположен по склону долины правого притока р. Суры - р. Шукша (Волжский бассейн) со сложным эрозионно-оползневым рельефом (площадь - 109 га). Перепады относительных высот могут достигать 70 м. Подстилающие почвы породы - соленосные глины, но могут быть песок и щебень. Почвы - выщелочные черноземы разной степени смытости и засоленности. Преобладают разнотравные галофитные луга с господством Silaum silaus (L.) Schinz et Thell., которые особенно сильно развиваются на залежах. Они отражают начальные этапы восстановления галофитной растительности и постепенно вытесняются из ее структуры [6].

В Малосердобинском районе известны 3 участка, из которых один уже охраняется - «Даниловская солонцовая поляна», два других предлагаются к охране: «Корзовая лощина» и «Чунакская солонцовая поляна».

«Даниловская солонцовая поляна» впервые обнаружена А.А. Соляновым [8] совместно с местным краеведом Т.И. Пчелинцевой [28, с. 317] в 1980-е годы. Участок площадью 5 га располагается в 1,5 км к юго-западу от с. Чунаки на территории Лопатинского лесхоза Даниловского лесничества (квартал № 15) на северной окраине выработанного торфяника «Гай». Относится к Волжскому бассейну на водоразделе pp. Чернавки (впадает в р. Няньгу) и Чунаки (впадает в р. Чардым, потом в р. Узу). Объект имеет форму вытянутой вдоль дороги поляны в мелколиственном лесу. Центральную часть поляны занимают сообщества многолетнеразнотравных галофитных степей с преобладанием Galatella linosyris (L.) Rchb. f. и Artemisia pontica L., а по периферии - сообщества 
многолетнеразнотравных галофитных лугов с господством Silaum silaus (L.) Schinz et Thell. и Galatella rossica Novopokr.

По нарушениям (на дороге) развиваются полукустарничковые луговые степи из Artemisia austriaca Jacq. и однолетнеразнотравные галофитные луга с доминированием Polygonum aviculare L.

На участке представлены самые разные ассоциации луговых степей (Artemisia armeniaca Lam.), остепненных (Calamagrostis epigeios (L.) Roth, Carex praecox Schreb., Agrostis tenuis Sibth., Poa angustifolia L.) и настоящих (Elytrigia repens (L.) Nevski, Carex melanostachya M. Bieb. ex Willd.) лугов [5, с. 205; 6; $7 ; 19 ; 20$, c. 23-25].

«Чунакская солонцовая поляна», найденная нами в 2009 г., находится в 3 км к северу от с. Чунаки и представляет собой опушку лесного массива «Вольница» на притоках р. Чернавка - правого притока р. Няньги (Волжский бассейн) [18; 19, с. 2325; 20; 28, с. 317]. Растительность прежде находилась под интенсивным антропогенным воздействием и в настоящее время отражает один из этапов восстановительной сукцессии галофитов.

На возвышенных и сильно засоленных участках развиваются сообщества полукустарничковых галофитных степей с преобладанием Artemisia nitrosa Weber et Stechm., в меньшей степени - Artemisia santonica L. На пониженных участках с меньшим засолением формируются сообщества многолетнеразнотравных галофитных степей с господством Galatella linosyris (L.) Rchb. f. По нарушениям формируются полукустарничковые луговые степи из Artemisia austriaca Jacq. и однолетнеразнотравные галофитные степи с доминированием Sedobassia sedoides (Schrad.) Freitag et G. Kadereit и Psammophiliella mиralis (L.) Ikonn.

На современном этапе восстановления галофитной растительности наблюдается постепенное вытеснение сообществ многолетнеразнотравных (Silaum silaus (L.) Schinz et Thell.) галофитных лугов и однолетнеразнотравных (Sedobassia sedoides (Schrad.) Freitag et G. Kadereit) галофитных степей.

«Корзовая лощина» примыкает к предыдущему участку, находится в 2 км севернее от с. Чунаки и располагается на притоках р. Чернавка - правого притока р. Няньги (Волжский бассейн). Ценность растительности этого участка была выявлена только в последние годы (2016-2017 гг.), так как раньше (2009 г.) она находилась под интенсивным антропогенным влиянием и была полностью разрушена. В настоящее время в связи с существенным сокращением выпаса скота здесь наблюдается активное восстановление галофитной растительности на залежах. Растительность также носит комплексный характер. По повышениям формируются сообщества полукустарничковых (Artemisia nitrosa Weber et Stechm.) и многолетнеразнотравных (Plantago salsa Pall.) галофитных степей, а по понижениям - сообщества галофитных лугов с доминированием Silaum silaus (L.) Schinz et Thell.

По нарушенным местам развиваются однолетнеразнотравные галофитные степи (Sedobassia sedoides (Schrad.) Freitag et G. Kadereit) и однолетнеразнотравные галофитные луга (Polygonum novoascanicum Klokov), которые отражают начальные этапы восстановления галофитной растительности.
В Неверкинском районе известны три засоленных участка: «Карноварский», «Келлеровский» и «Мансуровский» солонцы, обнаруженные (Л.А. Новикова, Ю.А. Вяль, Д.В. Полумордвинов с помощью местного краеведа - М.Г. Щербакова) в последние годы (2014 по 2018 гг.). Все участки имеют разное геоморфологическое положение: «Карноварский» располагается исключительно на водоразделе, «Мансуровский» занимает водораздельную поверхность и склоны преимущественно западной экспозиции, а «Келлеровский» - только склоны оврага. «Мансуровский солонец» был обнаружен нами в 2014 г. в результате экспедиции, предпринятой специально для поиска степных участков, описанных Б.А. Келлером [3, c. 181-182] на территории Пензенской области [27, c. 514]. В 2015 г. был найден «Келлеровский солонец», а в 2018 г. - «Карноварский».

Два последних участка располагается в 1-2 км к югу от с. Мансуровка на водоразделе левых притоков р. Елань-Кадада - рек Сормино и Карноварский овраг (Волжский бассейн) на высоте около 250260 м над у. м.

«Карноварский солонец» имеет площадь около 50 га и занимает исключительно водораздел, на котором хорошо выраженная мозаичность растительного покрова, связанная с различной степенью увлажнения и засоления почв. В структуре растительного покрова преобладают разнообразные галофитные степи (55\%), в меньшей степени - галофитные луга (22\%). На почвах с наибольшей степенью засоления почв преобладают полукустарничковые галофитные степи с доминированием Artemisia nitrosa Weber et Stechm. (33\%) и Bassia prostrata (L.) A.J. Scott (14\%). Хорошо представлены также многолетнеразнотравные с доминированием Limonium gmelinii (Willd.) Kuntze (2\%), Artemisia pontica L. (3\%), Galatella linosyris (L.) Rchb. f. (2\%) и однолетнеразнотравными с преобладанием Sedobassia sedoides (Schrad.) Freitag et G. Kadereit (1\%) галофитные степи. Наиболее пониженные элементы рельефа заняты многолетнеразнотравными с доминированием Silaum silaus (L.) Schinz et Thell. (8\%), и Galatella dracunculoides (Lam.) Nees (6\%), а также дерновиннозлаковыми с Puccinellia distans (Jacq.) Parl. (3\%), длиннокорневищными с Juncus gerardii Loisel. (2\%) и однолетнеразнотравными с Polygonum aviculare L. (3\%) галофитными лугами.

В условиях наименьшего засоления развиваются сообщества луговых степей (Artemisia armeniaca Lam.), остепненных (Calamagrostis epigeios (L.) Roth, Carex praecox Schreb., Agrostis tenuis Sibth., Poa angustifolia L. и настоящих (Elytrigia repens (L.) Nevski) лугов, а также лесостепных кустарников (Spiraea crenata L.).

«Мансуровский солонец» (площадь - около 400 га) занимает водораздел и склоны преимущественно западной экспозиции, а его растительность находится под постоянным антропогенным воздействием.

В растительности «Мансуровского солонца» [23; 24; 29] представлена как галофитные луга (33\%), так и галофитные степи (28\%). На водоразделах и на сильно засоленных почвах формируются галофитные степи, причем преобладают полукустарничковые степи с доминированием Artemisia nitrosa Weber et Stechm. (18\%) и Bassia prostrata (L.) A.J. Scott (5\%). 
Реже встречаются многолетнеразнотравные галофитные степи с доминированием Limonium gmelinii (Willd.) Kuntze (3\%). При нарушении растительного покрова (выпас) образуются корневищнозлаковые галофитные степи с преобладанием Bromopsis riparia (Rehm.) Holub, а также участием полукустарничка Artemisia santonica L. По депрессиям рельефа развивают многолетнеразнотравные галофитные луга: с Silaum silaus (L.) Schinz et Thell. (20\%) и с Galatella rossica Novopokr. (10\%), причем первая ассоциация занимает днище крупной балки и пойму реки, а вторая отмечается только по днищам неглубоких ложбин. Дерновиннозлаковая ассоциация галофитных лугов с доминированием Puccinellia distans (Jacq.) Parl. чаще развивается на пониженных местообитаниях, но под влиянием антропогенного фактора может встречаться и на возвышениях. Для этих сообществ характерен напочвенный покров из Nostoc sp. (от 20 до 40\%). В условиях меньшего засоления на участке формируются различные варианты степей $(19 \%)$ и лугов $(20 \%)$.

«Келлеровский солонец» (площадь - более 100 га) располагается в 2-х км на восток от с. Елшанка и на склонах оврага «Солонечный», впадающего в левый приток р. Елань-Кадада - р. Старый Карбухак - (Волжский бассейн). Впервые описан Б.А. Келлером в 1901 г. [3, с. 181-182], а позже был посещен нами в 2015 г. и назван в честь первооткрывателя. Почвенно-растительный покров этого участка сильно мозаичен в связи с разной степенью увлажнения и засоления почв разных геоморфологических элементов [3, с. 181-182].

В растительности «Келлеровского солонца» особенно хорошо представлены галофитные степи (56\%) по сравнению с галофитными лугами (16\%). Преобладают полукустарничковые галофитные степи (54\%) с участием Artemisia nitrosa Weber et Stechm. (29\%), Bassia prostrata (L.) A.J. Scott (21\%) и Artemisia santonica L. (4\%), которые занимают наиболее сухие и засоленные места. Значительно реже встречаются однолетнеразнотравные галофитные степи с доминированием Sedobassia sedoides (Schrad.) Freitag et G. Kadereit (2\%), которые практически представляют собой начальные этапы восстановления галофитной растительности. В более влажных элементах рельефа развиваются преимущественно многолетнеразнотравные с Silaum silaus (L.) Schinz et Thell. (14\%), в меньшей мере - дерновиннозлаковые с Puccinellia distans (Jacq.) Parl. (2\%) галофитные луга, но они могут значительно расширять свою площадь под влиянием антропогенного фактора. В растительности участвуют также и незасоленные степи (20\%) и луга $(6 \%)$ и кустарники $(2 \%)$ [21; 22; 29].

В Пензенском районе (включая быв. Кондольский) нами описано три засоленных участка: «Андреевский», «Васильевский» и «Ольшанский солонец», которые принадлежат разным речным бассейнам.

«Андреевский солонец» впервые найден А.А. Соляновым в 60-х гг. ХХ вв. [8]; находится близ с. Андреевка (площадь - 30 га) в пойме левого притока p. Хопер - p. Колышлей (Донской бассейн). По мере удаления от русла реки, в связи с разной степенью увлажнения почв, растительность участка сильно различается [12, с. 156-157].

Ближе к руслу реки в условиях большей влажности почв формируются болотистые луга с преобла- данием Deschampsia cespitosa (L.) P. Beauv. и заметным участием Cirsium canum (L.) All. и Jacobaea erucifolia (L.) G. Gaertn. et al. В этой ассоциации встречается Dacthylorhiza incarnata (L.) Soo, а также Inula salicina L., Cirsium esculentum (Siev.) C.A. Mey., Ononis arvensis L., Sium sisaroideum DC., Cenolophium denudatum (Hornem.) Tutin, Angelica palustris (Besser) Hoffm. и др.

Дальше от русла на менее влажных почвах образуются болотистые луга, в которых доминируют: Inula helenium L., Potentilla anserina L., Deschampsia cespitosa (L.) P. Beauv., Galium aparine L., где также довольно заметны Cirsium canum (L.) All. и Jacobaea erucifolia (L.) G. Gaertn. et al. и отмечается Sonchus palustris $\mathrm{L}$.

Наиболее возвышенные и более засоленные места заняты полукустарничковыми (Artemisia santonica), многолетнеразнотравными (Limonium donetzicum Klokov, Artemisia pontica L., Jacobaea erucifolia (L.) G. Gaertn. et al., Galatella linosyris (L.) Rchb. f.), однолетнеразнотравными (Sedobassia sedoides (Schrad.) Freitag et G. Kadereit) галофитными степями, а пониженные - дерновиннозлаковыми (Puccinellia distans (Jacq.) Parl.) и многолетнеразнотравными (Taraxacum bessarabicum (Hornem.) Hand.-Mazz.) галофитными лугами с участием Althaea officinalis L., Iris halophila Pall., Plantago maxima Jacq., Pedicularis dasystachys Schrenk и др. Интенсивное антропогенное влияние приводит к широкому распространению на территории участка именно галофитных лугов.

За дорогой развиваются остепненные луга с доминированием Calamagrostis epigeios (L.) Roth с участием Galatella rossica Novopokr., которые граничат с молодой залежью, находящейся на «бурьянистой» стадии демутации растительности (Artemisia absintium L. и Achillea nobilis L.).

В условиях меньшего засоления почв встречаются небольшие по площади сообщества с преобладанием Galatella villosa (L.) Rchb., Artemisia pontica, Festuca valesiaca Gaudin, где единично отмечаются Limonium donetzicum Klokov, Galatella linosyris (L.) Rchb. f., Hylotelephium stepposum (Boriss.) Tzvelev, Inula britannica $\mathrm{L}$.

Рядом располагаются разновозрастные залежи, находящиеся на разных этапах восстановления степной растительности. На молодых залежах растительность находится на «бурьянистой» (Artemisia absintium L. и Achillea nobilis L.) и «корневищной» (Calamagrostis epigeios (L.) Roth с участием Galatella rossica Novopokr.) стадиях демутации растительности.

Повсеместно получили распространение галофитные болота. На умеренно влажных участках болота с преобладанием Carex dilita M. Bieb. и C. disticha Huds. и участием Cenolophium denudatum (Hornem.) Tutin, Sium sisaroideum DC., где отмечаются редкие виды: Althaea officinalis L., Iris halophila Pall., Allium podolicum Błocki ex Raciborski et Szafer, Galatella linosyris (L.) Rchb. f., Plantago maxima Jacq., Ranunculus pedatus Waldst. et Kit., Pedicularis dasystachys Schrenk, а на более влажных - с господством Phragmites australis (Cav.) Trin. ex Steud., Eleocharis palustris (L.) Roem. et Schult. с участием Equisetum fluviatile L., Typha latifolia L. и др.

«Васильевский солонец» (впервые обнаружен Т.В. Горбушиной в 2002 г.) располагается в окрестностях с. Васильевка и имеет небольшую площадь 
(5 га); находится в пойме притока р. Колышлей p. Гончары (Донской бассейн). Растительность состоит из болот (Typha latifolia L., Schoenoplectus lacustris (L.) Palla, Eleocharis palustris (L.) Roem. et Schult. и др.) и лугов и испытывает интенсивное антропогенное воздействие. Здесь отмечены следующие виды: Carex diluta M. Bieb., Cirsium esculentum (Siev.) C.A. Меу. и C. canum (L.) All., Iris halophila Pall. [12, с. 157].

«Ольшанский солонец» (обнаружен Т.В. Горбушиной в 2006 г.) и найден в 2-х км к северо-западу от с. Ольшанка (южная окраина г. Пензы), имеет площадь - 20 га и включает часть поймы правого притока р. Ардым - р. Малиновки (Волжский бассейн). Находится справа от дороги, идущей в с. Ольшанку, и отделяется от дороги большим насыпным валом. Склоны вала имеют преимущественно южную экспозицию и в настоящее время на них восстановливается растительный покров из разнотравных (Salvia stepposa Schost., Galium ruthenicum Willd., Gypsophila volgensis Krasnova), бобовых (Astragalus onobrychis L.), корневищезлаковых (Bromopsis riparia (Rehm.) Holub) и дерновиннозлаковых (Stipa pennata L., S. tirsa Steven) луговых степей и др.

В пойме, окруженной залежами, располагается комплекс разнообразных сообществ. Высокие уровни поймы заняты лугами с участием мезофильных растений, способных расти при слабой степени засоления: Carex diluta M. Bieb., Cirsium esculentum (Siev.) C.A. Меу. и C. canum (L.) All., Jacobaea schwetzowii (Korsh.) Tatanov et Vasjukov, J. erucifolia (L.) G. Gaertn. et al., Melilotus dentatus (Waldst. et Kit.) Pers., Astragalus sulcatus L., Ononis arvensis L., Cenolophium denudatum (Hornem.) Tutin, Gladiolus tenius M. Bieb. Ha низких уровнях поймы развивается древесно-кустарниковая растительность: ивняки с участием Betula pendula Roth и низинные болота из Typha latifolia L. c примесью гигрофильного разнотравья: Lysimachia vulgaris L., Lythrum salicaria L., Eupatorium cannabinum L.

На небольшой площади (0,1 га) обнаружена ассоциация с доминированием Parnassia palustris L. и высокой плотностью особей Dacthylorhiza incarnata (L.) Soо и Herminium monorchis (L.) R. Br. [30-32].

В Сердобском районе пока известно только два солонца: «Красный» и «Сердобский», которые располагаются на левом притоке р. Хопер - р. Сердобе и ее притоках (Донской бассейн).

«Сердобский солонец» (найден А.А. Соляновым в 1962 г. [8]) располагается на южной окраине г. Сердобска и испытывает интенсивное антропогенное влияние (выпас скота, распашка под огороды).

На более сухих и засоленных местах образуются сообщества полукустарничковых галофитных степей (Artemisia santonica L.) и многолетнеразнотравных галофитных лугов (Plantago cornuti Gouan, Taraxacum bessarabicum (Hornem.) Hand.-Mazz.) с участием Atriplex intracontinentalis Sukhor., Triglochin maritima L., Tripolium pannonicum (Jacq.) Dobrocz.), Suaeda prostrata Pall., Glaux maritima L., Scorzonera parviflora Jacq, Jacobaea erucifolia (L.) G. Gaertn. et al. и др.

Участок сильно заболочен: значительную часть занимают болота из Typha latifolia L., Phragmites australis (Cav.) Trin. ex Steud., Schoenoplectus lacustris (L.) Palla и S. tabernaemontani C.C. Gmel., Eleocharis palustris (L.) Roem. et Schult., видами рода Carex и др. [12, с. $159-156 ; 18 ; 19 ; 20]$.
В 1962 г. А.А. Солянов обнаружил здесь Salicornia perennans Willd. [8], повторить находку пока не удалось.

«Красный солонец» (обнаружен А.Г. Моруновым в 2007 г.), находится на южной окраине пос. Красный (нежилой) на водоразделе двух левых притоков p. Сердобы - pp. Байка и Еланка (Донской бассейн). Ранее нам был известен солонец только с южной стороны села, но в 2018 г. обнаружен небольшой фрагмент солонца и с северной. Длительное время этот объект использовался как пастбище и не подвергался распашке, но в 2018 г. он был все-таки большей частью был распахан. Нуждается в изучении восстановительных процессов галофитной растительности.

Его растительность также отличается комплексным характером, связанным с чередованием степени увлажнения и засоления почв. На повышениях (меньшее увлажнение и большее засоление) образуются полукустарничковые (Artemisia santonica L.), многолетнеразнотравные (Limonium donetzicum Klokov с участием Allium praescissum Rchb.), однолетнеразнотравные (Sedobassia sedoides (Schrad.) Freitag et G. Kadereit) галофитные степи. Напротив, на понижениях (большее увлажнение и меньшее засоление) формируются дерновиннозлаковые (Puccinellia distans (Jacq.) Parl.), многолетнеразнотравные (Taraxacum bessarabicum (Hornem.) Hand.-Mazz., Amoria fragifera (L.) Roskov) и однолетнеразнотравные (Pulicaria vulgaris Gaertn.) галофитные луга с участием Iris halophila Pall., Allium praescissum Rchb., Jacobaea erucifolia (L.) G. Gaertn. et al.

На более влажных местоположениях развиваются болотистые луга с доминированием гигрофильных видов, выносящих засоление: виды рода Carex, Phragmites australis (Cav.) Trin. ex Steud., Beckmannia eruciformis (L.) Host, Schoenoplectus tabernaemontani C.C. Gmel., Cirsium esculentum (Siev.) C.A. Меу. и др.

На участке хорошо представлены разные типы лугов: от остепненных (Calamagrostis epigeios (L.) Roth) и настоящих (Bromopsis inermis (Leyss.) Holub, Elytrigia repens (L.) Nevski и др.) до болотистых (Deschampsia cespitosa (L.) P. Beauv.) [12, c. 160; 18; 20].

Таким образом, в Пензенской области в настоящее время обнаружено пятнадцать засоленных участков, из которых только два охраняются и имеют статус памятника природы: «Солонцовая степь» в Лунинском районе и «Даниловская солонцовая поляна» в Малосердобинском районе. Установлено, что и остальные засоленные участки обладают высокой флористической и фитоценотической ценностью и также нуждаются в охране и изучении. На их территории обнаружены многие уникальные виды, которые включены в Красные книги Пензенской области (2013) [10] и Российской Федерации (2008) [11].

Предлагаем включить в существующую систему ООПТ Пензенской области в качестве памятников природы еще тринадцать новых урочищ: в Колышлейском районе - «Жмакинский солонец», «Кайсаровский солонец»; в Лопатинском - «Литвиновский солонец»; в Малосердобинском - «Чунакская солонцовая поляна», «Корзовая лощина»; в Неверкинском - «Карноварский солонец», «Келлеровский солонец», «Мансуровский солонец»; в Пензенском «Ольшанский солонец», «Андреевский солонец», «Васильевский солонец»; в Сердобском - «Сердобский солонец», «Красный солонец». 


\section{Список литературы:}

1. Литвинов Д.И. Отчет действительного члена Общества // Годичный отчет Имп. МОИП за 1893 1894 гг. М., 1894. С. 10.

2. Келлер Б.А. Из области черноземно-ковыльных степей // Ботанико-географические исследования в Сердобском уезде Саратовской губернии. Казань: Типо-литография. Имп. Казан. ун-та, 1903. 130 с.

3. Келлер Б.А. Растительность засоленных почв СССР // Избранные сочинения. М.: Изд-во АН СССР, 1951. C. 177-211.

4. Спрыгин И.И. Из области Пензенской лесостепи. Ч. 3. Степи песчаные, каменисто-песчаные, солонцеватые на южных и меловых склонах. Пенза: Изд-во Гос. ком. по охране окружающей среды Пензенской области, 1998. С. 9-25.

5. Новикова Л.А. Состояние и изученность степной растительности в Пензенской области // Флористические и геоботанические исследования в европейской России: мат-лы всерос. науч. конф., посв. 100 -летию со дня рождения А.Д. Фурсаева (г. Саратов, 21-24 августа 2000 г.). Саратов: Изд-во Саратов. гос. пед. ин-та, 2000. С. 103-106.

6. Иванов А.И., Новикова Л.А., Чистякова А.А. Степные и лесостепные памятники природы бассейна реки Суры в Пензенской области // Устойчивое развитие административных территорий и лесопарковых хозяйств. Проблемы и пути их решения: матлы науч.-практ. конф. (М., 30-31 октября 2002 г.). М.: МГУЛ, 2002. С. 131-137.

7. Новикова Л.А., Неворотов А.И. Эдафические варианты степей Пензенской области и их охрана // Охрана растительного и животного мира Поволжья и сопредельных территорий: мат-лы всерос. науч. конф., посв. 130-летию со дня рождения И.И. Спрыгина (г. Пенза, 20-21 мая 2003 г.). Пенза: ПГПУ им. В.Г. Белинского, 2003. С. 227-230.

8. Солянов А.А. Флора Пензенской области. Пенза: ПГПУ им. В.Г. Белинского, 2001. 310 с.

9. Васюков В.М. Растения Пензенской области (Конспект флоры). Пенза: ПГУ, 2004. 184 с.

10. Красная книга Пензенской области Ч. 1. Грибы, лишайники, мхи, сосудистые растения. 2-е изд. / сост. А.И. Иванов, Л.А. Новикова, А.А. Чистякова и др.; под ред. А.И. Иванова. Пенза: ИПК Пензенская правда, 2013. 300 с.

11. Красная книга Российской Федерации: Растения и грибы / сост.: Р.В. Камелин и др.; под ред. Ю.П. Трутнев и др. М.: Товарищество науч. изданий КМК, 2008. 591 c.

12. The Euro+Med PlantBase - the information resource for Euro-Mediterranean plant diversity [El. resourse] // http://ww2.bgbm.org/EuroPlusMed.

13. Новикова Л.А., Разживина Т.Б. Галофильный компонент флоры Пензенской области в региональной Красной книге // Раритеты флоры Волжского бассейна: тезисы Рос. науч. конф. (г. Тольятти, 1215 октября 2009 г.). Тольятти: ИЭВБ РАН, 2009. C. $153-162$.

14. Чистякова А.А., Дюкова Г.Р. Структура почвенно-растительного покрова засоленных степных блюдец лесостепи // Известия ПГПУ им. В.Г. Белинского. 2010. № 17 (21). С. 32-38.

15. Новикова Л.А. Структура и динамика травяной растительности лесостепной зоны на западных склонах Приволжской возвышенности и пути ее оп- тимизации: автореф. дис. ... д-ра биол. наук. Саратов, 2012. $44 \mathrm{c}$.

16. Новикова Л.А. Охрана разнообразия степей на западных склонах Приволжской возвышенности // Раритеты флоры Волжского бассейна: докл. участников II Росс. науч. конф. (г. Тольятти, 11-13 сентября 2012 г.). Тольятти: «Кассандра», 2012. С. 175179.

17. Новикова Л.А. Разнообразие степей Пензенской области // Лесостепь Восточной Европы: структура, динамика и охрана: сб. ст. междунар. науч. конф., посв. 140-летию со дня рождения И.И. Спрыгина (г. Пенза, 10-13 июня 2013 г.). Пенза: Изд-во Пензенского гос. ун-та, 2013. С. 189-191.

18. Новикова Л.А., Панькина Д.В. Формирование растительности на засоленных участках в южных районах Пензенской области // Мониторинг экологически опасных промышленных объектов и природных экосистем: сб. статей VI Всерс. науч.-практ. конф. (г. Пенза, август 2012 г.) Пенза: РИО ПГСХА, 2012. C. $82-86$.

19. Новикова Л.А., Панькина Д.В. Характеристика засоленных участков в Малосердобинском и Сердобском районах Пензенской области // Вестник Мордовского гос. ун-та. 2013. Вып. 3-4. С. 21-26.

20. Панькина Д.В., Новикова Л.А. Степная растительность Малосердобинского и Сердобского районов Пензенской области // Актуальные проблемы науки и образования: труды XXIV науч.-практ. конф., посв. 70-летию Пензенского гос. ун-та (г. Пенза, 23-27 апреля 2013 г.) Ч. 1 / под ред. И.И. Артемова. Пенза: Изд-во Пензенского гос. ун-та, 2013. C. $228-230$.

21. Миронова Л.А., Новикова Л.А. Сохранение редкой галофитной растительности на «Келлеровском солонце» (Пензенская область) // Теория и практика гармонизации взаимодействия природных, социальных и производственных систем региона: мат-лы междунар. науч.-практ. конф., посв. Году экологии в Российской Федерации (г. Саранск, 1213 октября 2017 г.) / под ред. С.М. Вдовина (отв. ред.) и др. Саранск: Изд-во Мордовского гос. ун-та, 2017. С. 446-470.

22. Новикова Л.А., Миронова А.А., Васюков В.М Характеристика флоры и растительности «Келлеровского солонца» (Пензенская область) // Нива Поволжья. 2017. Вып. 4 (45). С. 109-114.

23. Новикова Л.А., Кулагина Е.Ю., Миронова А.А., Панькина Д.В. Ценный ботанический объект в Пензенской области («Мансуровскский солонец») // Известия высших учебных заведений: Поволжский регион. Сер. Естественные науки, 2016. Вып. 2. С. 19-29.

24. Новикова Л.А., Миронова А.А., Панькина Д.В., Глазунова Д.А. Новые сведения о галофитной растительности Пензенской области («Мансуровский солонец») // Сохранение разнообразия растительного мира в ботанических садах: традиции, современность, перспективы: мат-лы междунар. конф., посв. 70-летию Центрального сибирского ботанического сада (г. Новосибирск, 1-8 августа 2016 г.): Новосибирск: ЦСБС СО РАН, 2016. С. 212-214.

25. Лысенко Т.М. Растительность засоленных почв Поволжья в пределах лесостепной и степной зон. М.: Товарищество научных изданий КМК, 2016. 329 с. 
26. Юрицына Н.А. Растительность засоленных почв Юго-Востока Европы и сопредельных территорий. Тольятти: Кассандра, 2014. 164 с.

27. Горбушина Т.В., Новикова Л.А. Исследования Б.А. Келлера на территории Пензенской области (К 140-летию со дня рождения) // Экология и география растений и сообществ Среднего Поволжья: сб. всерос. конф. (г. Тольятти, 3-5 октября 2014 г.) / под ред. С.А. Сенатора, С.В. Саксонова, Г.С. Розенберга. Тольятти: Кассандра, 2014. С. 508-516.

28. Пчелинцева Т.И. Проблемы сохранения ценных участков растительности в Малосердобинском районе (Пензенская область) // Природное наследие России: сб. науч. ст. междунар. науч. конф., посв. 100-летию национального заповедного дела и Году экологии в России (г. Пенза, 23-25 мая 2017 г.). Пенза: Изд-во ПГУ, 2017. С. 317-318.

29. Vasjukov V.M., Novikova L.A., Pankina D.V., Shcherbakov M.G. Artemisia nitrosa Stechm. // Willdenowia. 2015. Vol. 45. P. 451.

30. Вяль Ю.А., Новикова Л.А., Карпова Г.А., Лойко Н.Г. Особенности генезиса гипноносных луговых почв в условиях Пензенской области // Нива Поволжья. 2013. Вып. 2 (27). С. 21-26.

31. Вяль Ю.А., Новикова Л.А., Лойко Н.Г., Мазей Н.Г., Карпова Г.А. Засоленные луговые почвы как компонент транссупераквальных ландшафтов лесостепи // Лесостепь Восточной Европы: структура, динамика и охрана: сб. ст. междунар. науч. конф., посв. 140-летию со дня рождения И.И. Спрыгина (г. Пенза, 10-13 июня 2013 г.). Пенза: Изд-во Пензенского гос. ун-та, 2013. С. 364-366.

32. Новикова Л.А., Вяль Ю.А., Леонова Н.А., Панькина Д.В. Геоботаническая характеристика «Ольшанского солонца» в Пензенской области // Нива Поволжья. 2014. Вып. 1 (30). С. 49-56.

Работа выполнена в рамках госзадания Института экологии Волжского бассейна РАН, тема (проект) № 0128-2014-0002 «Оценка современного биоразнообразия и прогноз его изменения для экосистем Волжского бассейна в условиях их природной и антропогенной трансформации" (направление 52 «Биологическое разнообразие»).

\title{
THE STUDY OF HALOPHYTIC VEGETATION OF THE PENZA REGION AND ITS PROTECTION
} (C) 2019

\author{
Novikova Lyubov Aleksandrovna, doctor of biological sciences, \\ professor of General Biology and Biochemistry Department \\ Penza State University (Penza, Russian Federation) \\ Vasjukov Vladimir Mikhailovich, candidate of biological sciences, \\ researcher of Phytodiversity Problems Laboratory \\ Institute of Ecology of the Volga River Basin of Russian Academy of Sciences \\ (Togliatti, Samara Region, Russian Federation) \\ Gorbushina Tatiana Viktorovna, candidate of agricultural sciences, researcher \\ State Natural Reserve «Privolzhskaya Forest-Steppe» (Penza, Russian Federation)
}

Abstract. 15 sites with saline soils have been identified and described in the Penza Region. Only 2 of them have a status of a nature sanctuary. They are the «Solontsovaya Steppe» in the Luninsky District and the «Danilovskaya Solontsovaya Polyana» in the Maloserdobinsky District. The other 13 sites are proposed to be included in the existing system of specially protected natural territories of the Penza Region as nature sanctuaries. They are «Zhmakinsky Solonetz», «Kaysarovsky Solonetz»(Kolyshley District); Litvinovsky Solonetz (Lopatinsky District); «Chunak Solontsovaya Glade», «Korzovaya Hollow» (Maloserdobinsky District); «Kellerovsky Solonetz», «Mansurovsky Solonetz», «Karnovarsky Solonetz» (Neverkinsky District); «Olshansky Solonetz», «Andreevsky Solonetz», «Vasilyevsky Solonetz» (Penza District); «Serdobsky Solonetz», «Krasny Solonetz» (Serdobsky District). We provide the following data for each site. This is the history of discovery (dates, researches), location, belonging to the basins of large rivers, approximate area, information about economic use in the past and the degree of anthropogenic disturbances, the characteristics of the relief and soil. The main attention is paid to the description of the nature of the distribution of halophilic vegetation, depending on the degree of salinity and soil moisture. Data on the steppes vegetation, meadows and swamps found in the described sites are also given. Dominant and rare species of vascular plants (in The Red Book of the Penza Region) are listed.

Keywords: halophytic vegetation; halophytes; Penza Region; specially protected natural areas; nature sanctuary; Red book; rare species; halophytic steppes; saline lowland marshes; halophytic meadows; saline; saline areas; protection of unique species and communities.

\section{ГРАНИЦЫ ВСХОЖЕСТИ СЕМЯН ФИТОМЕЛИОРАНТОВ В ПРИСУТСТВИИ ТОКСИЧНЫХ КОНЦЕНТРАЦИЙ ТЯЖЕЛЫХ МЕТАЛЛОВ}

(C) 2019

Ознобихина Анастасия Олеговна, аспирант кафедры техносферной безопасности Тюменский индустриальньй университет (2. Тюмень, Российская Федерация)

Аннотация. Цель исследования заключается в проведении биологического тестирования на начальных стадиях жизнеспособности растительных объектов в модельных условиях загрязнения тяжелыми металлами. 